\title{
High Affinity Immunoglobulin Gamma Fc Receptor I
}

National Cancer Institute

\section{Source}

National Cancer Institute. High Affinity Immunoglobulin Gamma Fc Receptor I. NCI

Thesaurus. Code C104238.

High affinity immunog lobulin gamma Fc receptor I (374 aa, $\sim 43 \mathrm{kDa}$ ) is encoded by the human FCGR1A gene. This protein is involved in the immune response and signal transduction. 